\title{
Educators Performance Management in Secondary Schools in Mauritius
}

\author{
Bhaugeerutty Vinod Sharma \\ $\mathrm{PhD}$ Student, Open University of Mauritius \\ Mauritius \\ Email: vsharma471@yahoo.co.uk
}

Received: November 10, 2016 Accepted: December 04, 2016 Published: December 16, 2016

doi:10.5296/ijhrs.v6i4.10476 URL: http://dx.doi.org/10.5296/ijhrs.v6i4.10476

\begin{abstract}
Given the rise of importance of globalisation, Mauritius needs to keep with the pace of competition in the global environment and the rapid change in technological development, it has become absolutely necessary for both the private and the public sector in the Mauritian economy to ensure that it is providing higher quality service to the customers and this includes the educational sector of the country also. The Government of Mauritius has taken into consideration of the youth as a vital resource of the economy which in the future will be the human capital of the Mauritian nation. Therefore, it is the responsibility of the government of Mauritius that there is the most effective and optimum use of the manpower of Mauritius in the various sectors of the economy including the secondary schools.

Taking into account the importance that the workforce in educational sector at all level be it primary, secondary and tertiary need to be effective and efficient so that outcomes such as innovative learning process, and to be result oriented for these objective the government has decided to implement a system which will help to identify the training needs of the educators and also to evaluate the level of performance of the teachers in these educational institutions.

The findings help to investigate the implementation of the Performance Management System (PMS) for educators in secondary schools and how it motivates the educators to the best of their ability and it encourages them to work harder so as to increase the quality level of service delivered in the education sector.

The study tried to analysed how the implementation of PMS for educators in secondary schools has been effective and that the teacher's that a clear understanding of the system and that they see the performance management system as an effective tool for secondary school and how it can help policy makers to do the required changes to improve the performance in
\end{abstract}


the education sector at secondary level.

Keywords: Pay research bureau, School based management, Performance management system, Performance appraisal form

\section{Introduction}

Globalisation together with a competitive world environment and developments in technology have made it imperative for all sectors in the economy to provide better services to their clients and secondary schools are no exception. The Government of Mauritius realised that human capital is an important resource with which Mauritius has been endowed, and that optimum use needs to be made of this resource in all sectors and the education sector was no exception. Being aware that public officers working in schools (both primary and secondary) need to be dynamic, proactive, vibrant, forward looking, innovative, effective, performing and result oriented, it became imperative to put in place a system which would allow not only to evaluate the performance of educators working in these schools but also to encourage educators to participate in seminars, workshops and to upgrade themselves in their field.

In line with the recommendations of the Task Force on Performance Management, the Pay Research Bureau (PRB) report 2008 recommended, inter alia, that all Ministries/Departments should evaluate and review periodically their performance in relation to established targets. The Education Commission of 2008recommended that all schools should put in place school-based management (SBM) by the year 2010. The SBM should comprise a number of key elements, of which the development of formal procedures and resources for educator's appraisal and development. Schools have been advised, and in fact they all pledged, to establish an educator performance system by the end of 2010 .

"Providing quality education to all" is the vision of the Ministry of Education. To achieve its vision through the nine-year schooling, it is important that everyone in the education system perform to the best of their ability to deliver their services. Thus, it is essential to look at different training needs in order to evaluate the teaching personnel in secondary schools.

The Performance Management System (PMS) has emerged from the need to build a modern and efficient teaching profession in Mauritius whereby the main focus would be on results and improvement in the delivery of services with educators assuming more of a role of facilitators. It aims at improving performance by focusing on key areas of the activity which are identified through strategic planning processes since the PMS is a mechanism for improving teaching and learning through meaningful interaction between the educator and the taught. It is important as an integrated reform strategy whereby better results are obtained from the schools, teams and individuals by understanding and managing performance within an agreed framework of planned goals, objectives, standards and competencies.

After several years of strategic planning the government of Mauritius has introduced the PMS on a pilot basis in three different administrative departments in the year 2006. The idea 
behind the introduction was to improve the public sector for better economy and to act responsively to the fast moving modernized management.

The Pay Research Bureau (PRB) is the organization in Mauritius that governs the pay review of the public sector with reference to the private educational schools came with the trend for the alignment of conditions of service, salaries, qualifications and competencies with state schools. The objective for this approach was to dispensed uniform and standard education to all in a larger society. From the recommendations in the PRB report (2008), strategies of the performance appraisal and performance related pay would take place as from $1^{\text {st }}$ August 2008, in order to optimize resources.

So the PMS was introduced in the Secondary Schools as from 2008 as a pilot project in Zone 3 of the education system as a means to measure its effectiveness in State Secondary Schools in Mauritius. The implementation of PMS was expected to help obtain better results from educators, department members and the schools as a whole, as both appraiser and appraisee understand and manage performance as per an agreed framework for planned goals, objectives, standards and competencies.

It is agreed that educators' professional competence and conscientiousness are the keys to the delivery of quality education in schools. In a well-designed educator-appraisal system, the instruments and procedures can constitute valuable professional development for educators and enable the school management to assess educators' performance. The educator appraisal system assists in recognizing and encouraging good performance, identifying areas for development, and improving overall performance of educators.

A Task Force on Performance Management was set up by the government to create a Framework for all Departments/Ministries to adopt strategic planning and measure achievement of organizational objectives and divisional work targets against established performance indicators. The Performance Management Framework Draft highlighted that appraisal of an employee should start with a performance agreement between appraiser and the appraisee on predetermined work plan with continuous reviews of performance and assessment of development needs.

Properly carried out PMS should be seen as a means of increasing the engagement and motivation of people by providing positive feedback and recognition. It is an ongoing process between Appraiser and Appraisee whereby feedback is given and shortcomings addressed immediately.

In fact, PMS is built on openness and is expected to facilitate:

- the alignment of educators on the strategic goals of their schools;

- $\quad$ systematic and proactive educators development; and

- foster good school wide relations between students and management so as to develop better understanding and engagement. 


\section{Al Macrothink}

International Journal of Human Resource Studies

ISSN 2162-3058 2016, Vol. 6, No. 4

An effective educator performance management system should encompass the key professional responsibilities and key performance areas like:

- teaching responsibilities, such as planning and preparation of lesson plans, teaching techniques, classroom management, classroom environment, curriculum knowledge and student assessment:

- school-wide responsibilities such as contribution to curriculum leadership, school-wide planning, school goals, the effective operation of the school as a whole. Pastoral activities and student counselling, and to community relationships;

- management responsibilities such as planning, decision-making, reporting, professional leadership, resource management.

- $\quad$ attitude such as empathy

PMS is education is based on two major themes

- Identification of vision, mission and broad objectives of the school, for example the school strategic plan

- Performance appraisal of both school as an organization and Individuals, providing feedback and encouragement

The primary aim of PMS in education is to enhance performance at all levels by focusing on key areas of activity to be delivered which are identified through strategic planning processes. The strategic planning process includes:

- $\quad$ PLANNING work and setting targets in line with school objectives

- Continually MONITORING performance

- Developing CAPACITY to perform

- Periodically RATING performance

- REWARDING good performance and

- TACKLING poor performance

There may be many models or blueprints for a performance management system. Some local and overseas experience indicate that for an effective performance appraisal system, differentiated procedures and requirements should be designed to suit educator's professional development needs and their professional life cycle. It involves the following stages: 


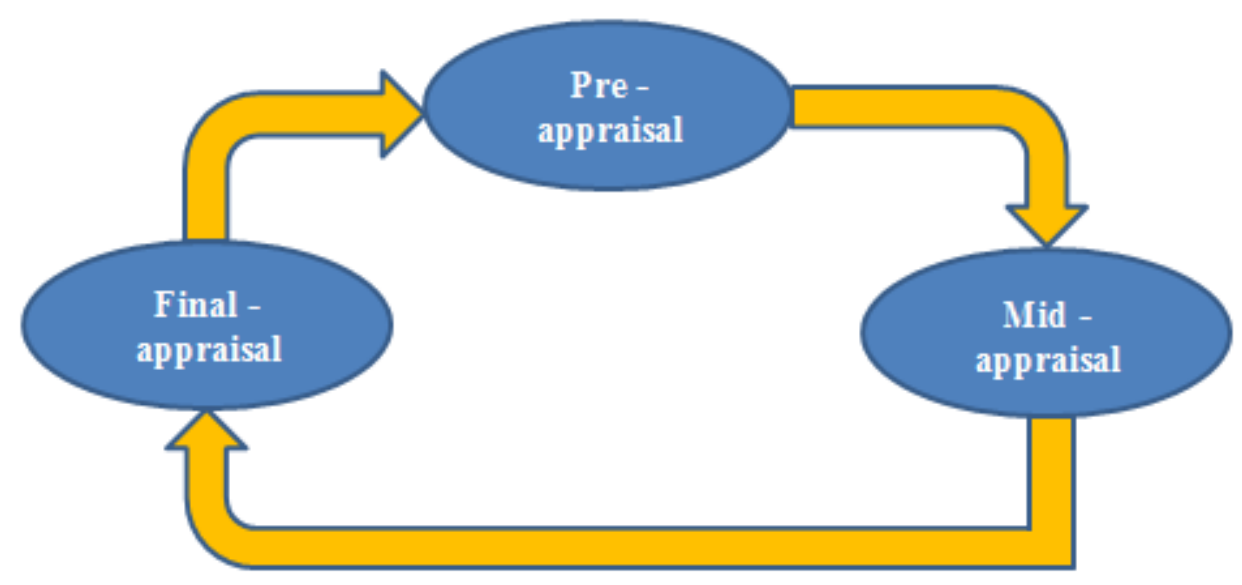

Source: Adapted from Ministry of civil service \& administrative reforms (March 2013)

Figure 1: Performance Appraisal Process at Individual level

- Pre-appraisal

In the planning and agreeing on Performance stage, the school appoints a convener/appraiser to take charge of the development or improvement of the educator performance management system. The appraiser discusses and records priorities and objectives with each of the educators in his/her team and discuss how progress will be monitored through a two way communication between appraiser and appraisee. A work plan is developed and agreed upon by both parties.

At this stage the Appraisee fills in section 1 of the Performance Appraisal Form (PAF) from the "Guide to performance management in the Civil service" and the appraisee and appraiser discuss the work plan for the period. The work plan consists of the job's Key Result Area (KRAs)/Key tasks and the Performance Standards. The work plan also provides for the identification of the competencies required for the effective performance of the job. Finally, both the appraisee and appraiser agree on the work plan and fill in section 2 .

- Mid-appraisal is the managing performance stage

At mid-term of the phase, the appraisee is called upon to carry out a self-evaluation of the achievements and performance gaps as per the work plan, following which the appraiser conducts a formal interview with the appraisee to review and record progress made on the performance agreement and to inform him of the areas that need improvement.

During this stage the appraiser fixes the mid-term appraisal meeting and informs the appraisee well in advance (preferably 2 weeks before). The appraisee fills in sections 3.1 and 3.2 and submits the original PAF to appraiser.

During the mid-term meeting, the appraiser and appraisee discuss on progress achieved on Performance Agreement (PA) and fill in sections 3.3 and 3.4 of PAF. It identifies the weaknesses and is then monitored in order to help the employee to improve. 
- Final Appraisal is the Reviewing Performance stage.

At the end of the one year cycle, the appraiser reviews, evaluates and documents the performance of the appraisee during the appraisal period. The appraisee is called upon to once again self-evaluate his/her performance against the work plan agreed upon during the pre-appraisal stage. The appraisee fills in sections 4.1 and 4.2 and submits the original PAF to appraiser.

The appraiser carries out a final interview to give the appraisee specific performance information in regard to good performance and to provide any pertinent suggestions for improvement, and action plans are developed in consultation with both parties for deficient areas. The appraisee fills in sections 4.1 and 4.2 from the "Guide to performance management in the Civil service" and submits the original PAF to appraiser.

This type of communication and documentation allows opportunity for an appraisee to adhere to the expected results for the post during the next appraisal year.

In Mauritius, little research has been done in schools to evaluate educator's performance as the PRB report. Lukheenarain, (2009) discussed the weaknesses and biases that can cause the PMS to fail include absence of participation, organization culture, low self-worth, high expectations and inaccurate ratings published in a press article, heads of department and heads of school are said to be complaining about an overload of paperwork. Performance Management is seen as a good thing where educators can have their say in their performance appraisal. However, loads of administrative work coming with the system can be a hurdle.

It is observed that a number of questions justified performance management in schools leads to improved performance or simply accountability. It is only through a further research on the effectiveness of performance management for educators in State Secondary that it would be possible to bring out the strengths and weaknesses of the system and help to make recommendations to the authorities on how to improve the system so as to fulfill the vision of the Ministry of Education of 'Quality education for All' and also make it sustainable in all state secondary schools in the future.

\section{Conclusion}

For a successful implementation of the system the management should communicate clearly the importance of the proposed one and gain the acceptance of all the employees regarding the benefit and the win-win situation. The end results of the system is for helping all staff to be motivated, acquire more confidence in themselves, committed toward their work, working together in the same direction with the mission statement stated by the management and finally having a clear vision of the company.

Consequently the management should take advantage of the feedback received from the employees while conducting the meeting. This PMS will help the management to be closed to their staff and thus this creates a better understanding to each other. It will be worthwhile that the organization see this process as a dynamic, real time feature of the work life. In another word it should not be a standalone process, it should be rooted in the organization's core 


\section{Macrothink}

International Journal of Human Resource Studies

ISSN 2162-3058 2016, Vol. 6, No. 4

strategy. It should also be based on a clear understanding of what role it will play in achieving business goals.

\section{References:}

http://www.tbs-sct.gc.ca/pol/doc-eng.aspx?id=14226

http://civilservice.govmu.org/English/Documents/pms\%20secretariat/understanding\%20PIF $\% 20$ and\%20PIP.pdf

http://www.minedu.govt.nz/NZEducation/EducationPolicies/Schools/SchoolOperations/Empl oymentConditionsAndEvaluation/PerformanceManagementSystems/PMS

Kot Zot Mauritius Portal Mauritius Newspaper Syndicating Mauritian News.

Armstrong, M. (2007) Performance Management. Key Strategies and Practical Guidelines.3rd ed., Kogan Page India Private Limited, New Delhi.

Goel, D., (2008) Performance Appraisal and Compensation Management - a Modern Approach. India, Prentice-Hall.

\section{Copyright Disclaimer}

Copyright for this article is retained by the author(s), with first publication rights granted to the journal.

This is an open-access article distributed under the terms and conditions of the Creative Commons Attribution license (http://creativecommons.org/licenses/by/3.0/). 